\title{
SOME MEASUREMENTS OF THE TRANSMISSION OF ULTRA-VIOLET RADIATION THROUGH VARIOUS FABRICS
}

\author{
By W. W. Coblentz, R. Stair, and C. W. Schoffstall
}

ABSTRACT

In this paper measurements are described of the transmission of ultra-violet and visible radiation through fabrics made of various kinds of material-cotton, natural silk, rayon (artificial silk), linen, and wool.

The source of radiation was a quartz mercury arc lamp from which ultraviolet radiation was obtained by filtration through a Corning purple glass $986 \mathrm{~A}$, and the visible radiation was isolated by filtration through a yellowish-green glass.

By examining black and white samples of the same material, it was possible to eliminate the effect of the radiation transmitted through the openings between the individual threads and thus determine the amount of radiation transmitted directly through the yarn.

Fabrics of close-weave and open-weave (twill, satin, voile) material were examined. The results obtained on these different weaves are in agreement in showing that, comparing materials having the same weight, there is practically no difference in the amount of ultra-violet transmitted through bleached samples of cotton, linen, viscose rayon, and the rayon made by the cellulose acetate process.

The fresh, white, natural silk is almost as transparent as bleached cotton, while wool is only about half as transparent to ultra-violet solar radiation as bleached cotton.

In all cases when the fabric is dyed, or slightly yellowed with age, the ultraviolet transmission through the thread is greatly decreased. Hence, as is to be expected in comparing various kinds of dyed fabries, the one having the largest openings between the threads transmits the most ultra-violet.

\section{CONTENTS}

Page

I. Introduction

II. Experimental procedure

III. Discussion of the transmission data on fabrics

1. Cotton fabrics.......... 119

2. Linen fabrics _. _ _ _ _ _

3. Silk fabrics

4. Wool fabrics

5. Rayon fabrics.

6. Concluding remarks........ 122

IV. Transparency of feathers and animal tissue $\ldots \ldots \ldots$ $100438^{\circ}-28-1$ 


\section{INTRODUCTION}

An important utilitarian problem is the transparency or opacity of fabrics to solar radiation: (1) Great transparency when it is desired to expose the body to the short wave length ultra-violet rays which have a therapeutic value, and (2) great opacity when it is desired to shield the body from excessive amounts of these rays, as, for example, the clothing and head gear of troops and expeditions in tropical countries.

Incidentally the problem promises to be of especial interest optically in connection with the question of the transmission of light through an optically inhomogenous medium in the form of a twisted thread which consists of a great many strands of homogenous material (cellulose) having a low coefficient of absorption when undyed and usually a rather high coefficient of selective absorption when dyed.

As a result of internal reflection within the individual fibers or single threads (if it is artificial material), a large part of the incident radiation is returned upon its original path, and if the absorption is low, an appreciable amount of the remainder is transmitted either directly through, or by successive total reflection within, the individual strands of the yarn.

From our earlier studies of thin films of cellulose ${ }^{1}$ either as a lacquer or as a covering for airplane fabrics, it was found that a slight discoloration, caused by exposure to ultra-violet radiation, greatly decreases the transmission of these rays. From this observation, and also from the fact that fabrics are usually colored with dyes that absorb the ultra-violet, it was recently indicated ${ }^{2}$ that there is no justification for advocating rayon (artificial silk) in preference to natural silk, cotton, or linen fabrics as a therapeutic medium for transmitting ultra-violet rays. In fact, as shown in the present paper, if any preference is to be given to the composition of the fabric, instead of the kind of weave, then the material of pure white cellulose (cotton and regenerated cellulose rayon) is somewhat better than wool and natural silk for transmitting the ultra-violet rays.

\section{EXPERIMENTAL PROCEDURE}

Since the material examined was inhomogeneous, causing a relatively large scattering of the light, it was impracticable to determine the spectral transmission with a spectroradiometer. Moreover, for the purposes of the present inquiry it was sufficient to determine the transmission of the fabric for the band of ultra-violet radiation between 290 and $320 \mathrm{~m} \mu$ (which rays are known to have a therapeutic value) relative to the transmission of a spectral region of

1 Coblentz and Kahler, B. S. Sci. Paper No. 342, 15, p. 215; 1919.

3 Coblentz, Physical Therapeuties, 45, p. 407; 1927. Coblentz, Trans. Illum. Eng. Soc., 23, p. 247; 1927. 
longer wave lengths in the yellow-green of the visible spectrum, where selective absorption is less pronounced or nonexistent, which condition obtains in white fabrics.

Using a 110-volt quartz mercury arc as a source, an image of the burner was focused by means of a quartz lens of $18 \mathrm{~cm}$ focal length upon a Bi-Ag thermopile ${ }^{3}$ having a surface 3 by $9 \mathrm{~mm}$ (see fig. 1a). This was covered with a window of quartz $2.5 \mathrm{~mm}$ in thickness to exclude long wave length, low-temperature radiation from the cloth, which may become heated ${ }^{4}$ when exposed to the quartz lamp, and consequently radiate to the thermopile. This effect was found negligible in the case of thin material which did not absorb much of the incident radiation.

The cloth under examination was placed directly over this quartz window in order to have it as close as possible to the thermopile receiver, so as to intercept as much as possible of the radiation which emanates diffusely from the underside of the cloth. In order to have reproducible conditions, the cloth was held flat by placing over it the glass which was used for isolating either the ultra-violet or visible radiation.

The filter for isolating the ultra-violet radiation at 250 to $400 \mathrm{~m} \mu$ consisted of a plate of Corning purple glass G986A, which is quite opaque to the visible and the infra-red rays. The ultra-violet spectral transmission of this glass is depicted in Figure 1, as observed when the sample was new. After it had been exposed to ultraviolet radiation from the quartz mercury are lamp in the course of these and other measurements, the transmission remained practically unchanged. However, the effect of prolonged exposure to ultraviolet radiation is to decrease the transmission of this screen in the extreme ultra-violet wave lengths. That such a change was not sufficient to affect our work was determined by measurements on the same samples of fabrics at the beginning and at the completion of this investigation. For some of our measurements we used a combination of G986A and a piece of window glass, No. 4, by means of which filter the ultra-violet is separated into two bands, at 250 to $310 \mathrm{~m} \mu$ and 310 to $400 \mathrm{~m} \mu$, respectively, as shown on Figure 1.

The filter used for isolating the yellow and green in the visible spectrum consisted of a greenish-yellow glass, shade No. 3 of Willsonweld (or Bausch and Lomb) glass, which is opaque to the ultraviolet and the infra-red (see fig. 1). Usually no transmission measurements were made on colored fabrics, because this screen is not monochromatic and, hence, is best adapted for measurements on white and black fabrics.

In order to obtain the amount of ultra-violet and visible radiation transmitted through the openings between the thread, measurements

${ }^{3}$ Coblentz and Kahler, B. S. Sci. Paper No. 378, 16, p. 233; 1920.

- Coblentz, B. S. Bull. No. 196, 9, p. 283; 1913. 
were made on white and on black samples of the same kind of cloth, the black threads having practically zero transmission. In some cases the cloth was dyed black, and since the same results were obtained by the two methods, when the samples were small it was quicker to blacken part of the fabric by means of india ink. Repeated tests showed that the blackening of the threads with india ink (Higgins drawing ink) was satisfactory.

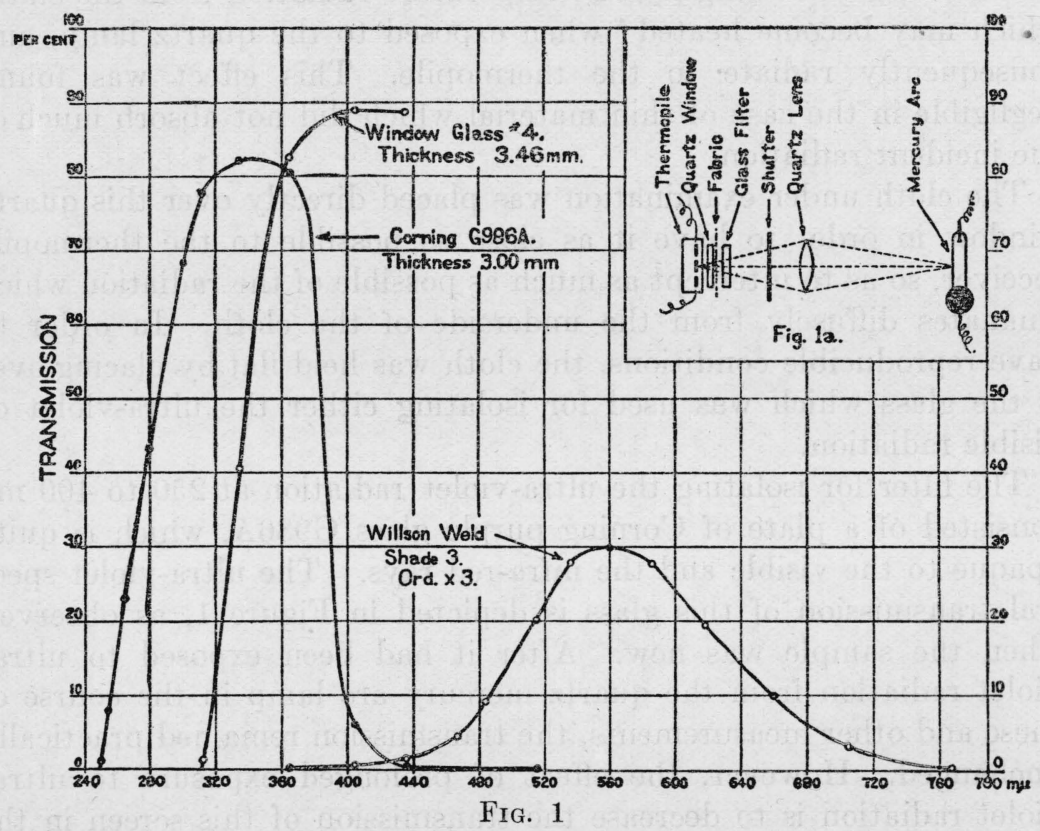

The electric current generated by means of the thermopile when exposed to radiation was measured by means of an ironclad Thomson galvanometer. ${ }^{5}$ By noting the galvanometer deflection, with and without the cloth placed over the thermopile receiver, the percentage of transmission was obtained. These values for both the ultra-violet and the visible region of the spectrum are assembled in Tables 1 and $2 .^{6}$

3 Coblentz, B. S. Bull. No. 282, 13, p. 423; 1916.

- Information on the use of thermopiles, etc., in radiometry, is given in B. S. Bulls. Nos. $85,188,229$, $282,319,378$, and 413 , obtainable from the Superintendent of Documents, Washington, D. C. 
TABLE 1.-Percentage of transmission of ultra-violet radiation through various substances

[Columns 2, 3, and 4 give the total transmission through the threads and intervening spaces] COTTON (CELLULOSE)

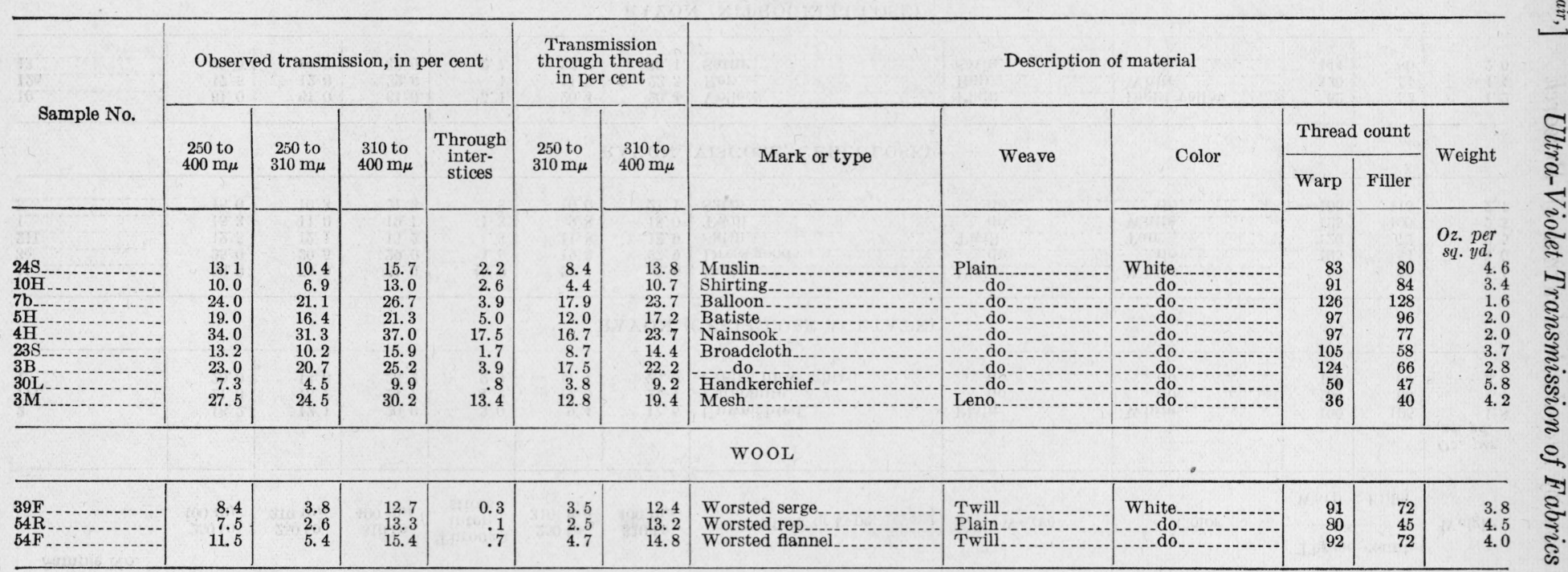

LINEN (CELLULOSE AND LIGNOSE)

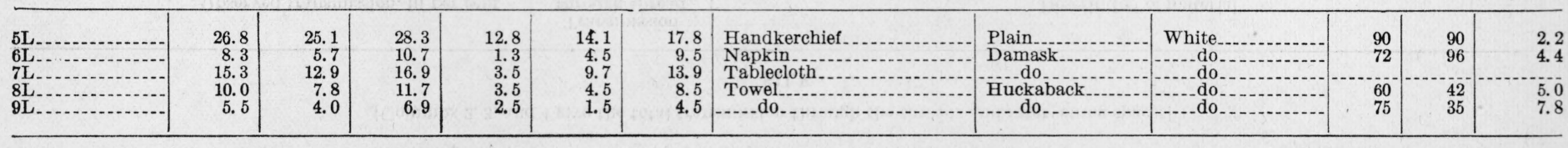


TABLE 1.-Percentage of transmission of ultra-violet radiation through various substances-Continued

[Columns 2, 3, and 4 give the total transmission through the threads and intervening spaces]

SILK

\begin{tabular}{|c|c|c|c|c|c|c|c|c|c|c|c|c|}
\hline \multirow{3}{*}{ Sample No. } & \multicolumn{4}{|c|}{ Observed transmission, in per cent } & \multicolumn{2}{|c|}{$\begin{array}{l}\text { Transmission } \\
\text { through thread } \\
\text { in per cent }\end{array}$} & \multicolumn{6}{|c|}{ Description of material } \\
\hline & \multirow{2}{*}{$\begin{array}{c}250 \text { to } \\
400 \mathrm{~m} \mu\end{array}$} & \multirow{2}{*}{$\begin{array}{c}250 \text { to } \\
310 \mathrm{~m} \mu\end{array}$} & \multirow{2}{*}{$\begin{array}{c}310 \text { to } \\
400 \mathrm{~m} \mu\end{array}$} & \multirow{2}{*}{$\begin{array}{c}\text { Through } \\
\text { inter- } \\
\text { stices }\end{array}$} & \multirow{2}{*}{$\begin{array}{c}250 \text { to } \\
310 \mathrm{~m} \mu\end{array}$} & \multirow{2}{*}{$\begin{array}{l}310 \text { to } \\
400 \mathrm{~m} \mu\end{array}$} & \multirow{2}{*}{ Mark or type } & \multirow{2}{*}{ Weave } & \multirow{2}{*}{ Color } & \multicolumn{2}{|c|}{ Thread count } & \multirow{2}{*}{ Weight } \\
\hline & & & & & & & & & & Warp & Filler & \\
\hline $7 \mathrm{H}$ & $\begin{array}{l}16.2 \\
21.0 \\
20.0\end{array}$ & $\begin{array}{l}12.1 \\
15.7 \\
14.0\end{array}$ & $\begin{array}{l}20.0 \\
24.7 \\
25.2\end{array}$ & $\begin{array}{l}3.0 \\
4.2 \\
2.9\end{array}$ & $\begin{array}{r}9.4 \\
12.0 \\
11.4\end{array}$ & $\begin{array}{l}17.5 \\
21.4 \\
23.0\end{array}$ & $\begin{array}{l}\text { Unweighted. } \\
\text { Parachute } \\
\text { Crêpe, unweighted. }\end{array}$ & \begin{tabular}{|c|} 
Plain \\
\hdashline do
\end{tabular} & $\begin{array}{l}\text { White } \\
\end{array}$ & $\begin{array}{l}100 \\
130 \\
135\end{array}$ & $\begin{array}{r}105 \\
86 \\
80\end{array}$ & $\begin{array}{l}\text { Oz. per } \\
\text { sq. yd. } \\
1.8 \\
1.4 \\
2.0\end{array}$ \\
\hline \multicolumn{13}{|c|}{ RAYON (CELLULOSE ACETATE) } \\
\hline $\begin{array}{l}4 \mathrm{c}-1 \\
2 \mathrm{c} \\
1 \\
5\end{array}$ & $\begin{array}{l}60.0 \\
25.0 \\
12.5 \\
15.3 \\
16.0\end{array}$ & $\begin{array}{l}59.0 \\
20.5 \\
12.1 \\
11.0 \\
10.3\end{array}$ & $\begin{array}{l}61.0 \\
29.0 \\
13.2 \\
19.1 \\
21.3\end{array}$ & $\begin{array}{r}43.0 \\
1.5 \\
.3 \\
1.3 \\
.3\end{array}$ & \begin{tabular}{r|}
28.1 \\
19.3 \\
11.8 \\
9.8 \\
10.0
\end{tabular} & $\begin{array}{l}31.6 \\
27.9 \\
12.9 \\
18.0 \\
21.1\end{array}$ & $\begin{array}{l}\text { Voile-_... } \\
\text { Dress goods } \\
\text { Satin-. } \\
\text { Twill } \\
\text { Satin }\end{array}$ & \begin{tabular}{|c|} 
Plain \\
Twill \\
do
\end{tabular} & $\begin{array}{l}\text { White } \\
\text { Tan } \\
\text { White }\end{array}$ & $\begin{array}{r}63 \\
105 \\
120 \\
125 \\
105\end{array}$ & $\begin{array}{r}66 \\
54 \\
72 \\
100 \\
115\end{array}$ & $\begin{array}{l}1.4 \\
3.0 \\
2.5 \\
2.3 \\
2.7\end{array}$ \\
\hline \multicolumn{13}{|c|}{ RAYON (VISCOSE, CELLULOSE) } \\
\hline $10 \mathrm{a}-10$. & $\begin{array}{l}61.0 \\
17.5 \\
29.0\end{array}$ & $\begin{array}{l}61.0 \\
12.0 \\
24.3\end{array}$ & $\begin{array}{l}61.0 \\
22.6 \\
32.0\end{array}$ & $\begin{array}{l}5.1 \\
.1 \\
2.7\end{array}$ & $\begin{array}{l}20.4 \\
11.9 \\
22.2\end{array}$ & $\begin{array}{l}20.4 \\
22.5 \\
30.1\end{array}$ & $\begin{array}{l}\text { Voile } \\
\text { Rep } \\
\text { Satin }\end{array}$ & \begin{tabular}{|l|} 
Plain \\
Rep \\
Satin
\end{tabular} & $\begin{array}{l}\text { Light yellow } \\
\text { White.... }\end{array}$ & $\begin{array}{r}62 \\
120 \\
144\end{array}$ & $\begin{array}{l}52 \\
54 \\
80\end{array}$ & $\begin{array}{l}1.2 \\
4.4 \\
2.0\end{array}$ \\
\hline \multicolumn{13}{|c|}{ RAYON (NITROCELLULOSE) } \\
\hline $14 \ldots$ & 20.1 & 17.5 & 22.5 & 0.1 & 17.4 & 22.4 & Satin & Satin & White .... & 164 & 125 & 2.6 \\
\hline
\end{tabular}


RAYON (CUPRAMMONIUM)

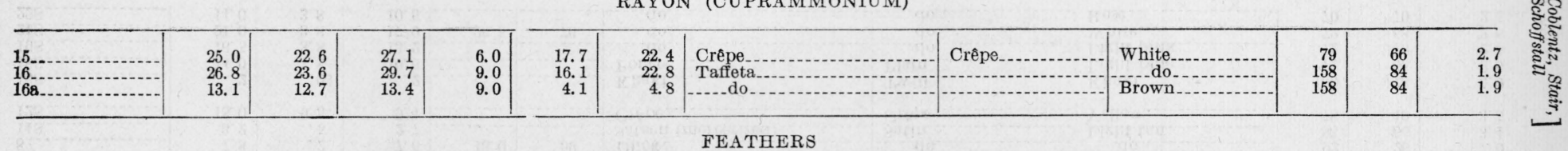

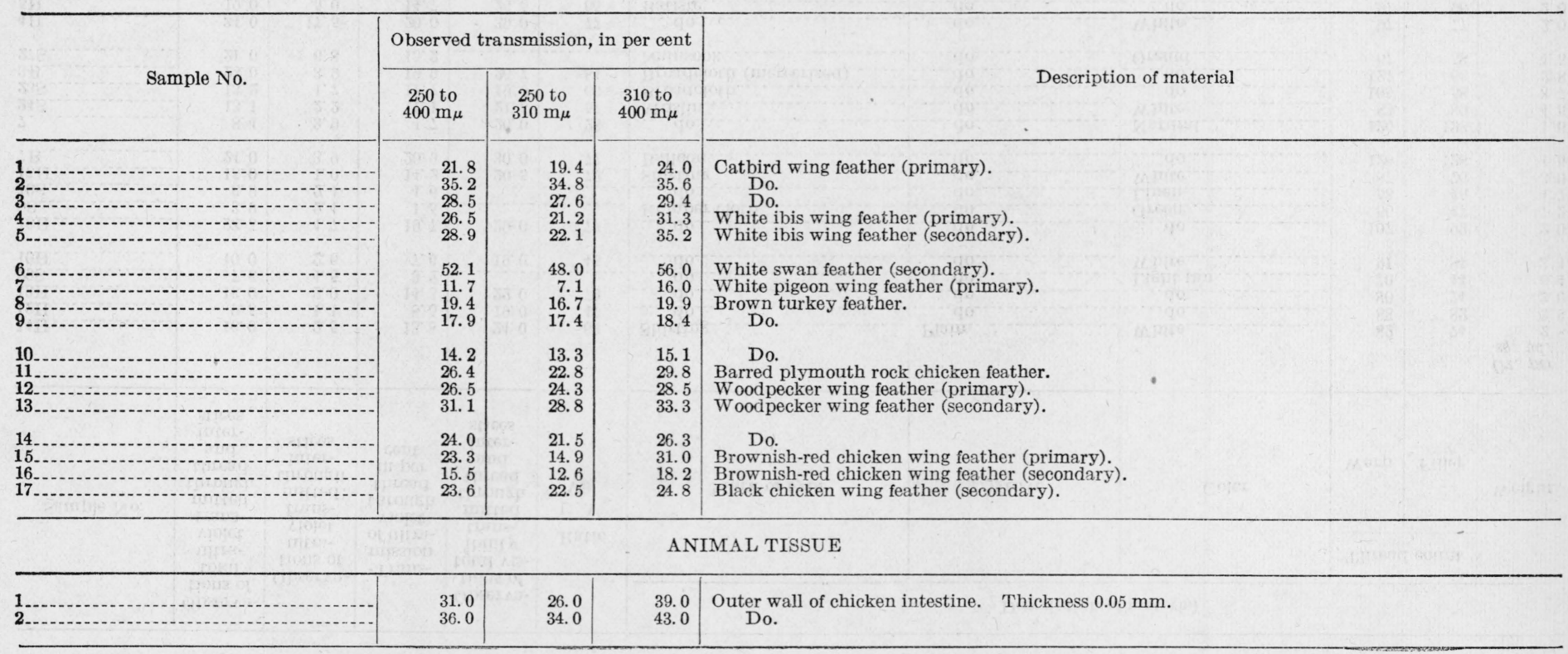


TABLE 2.-Transmission in per cent of the total ultra-violet and visible radiation observed through various fabrics, using screen G986A for columns 2,3 , and 4, and the screen transmitting visible radiation for column 5 COTTON (CELLULOSE)

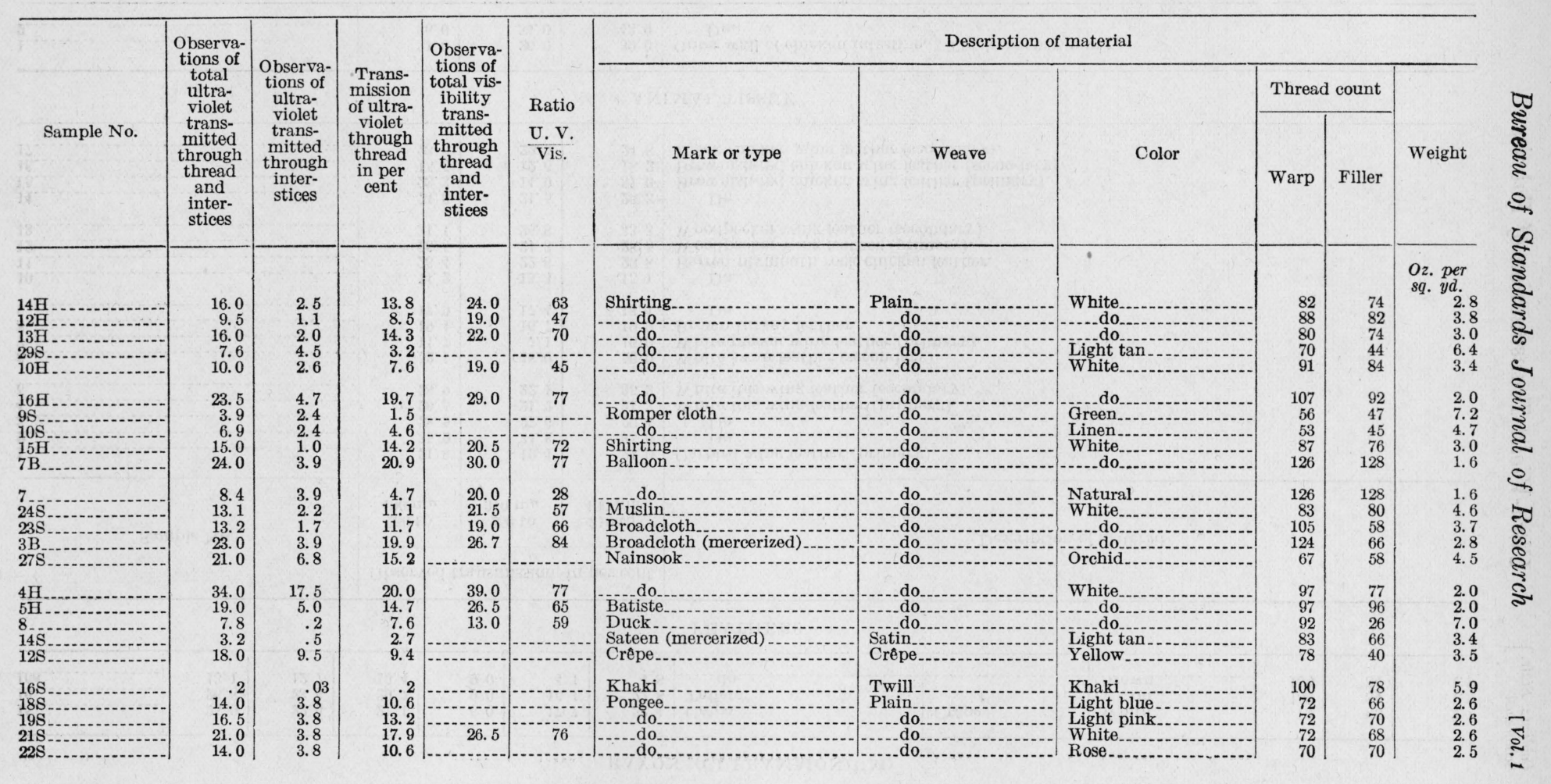




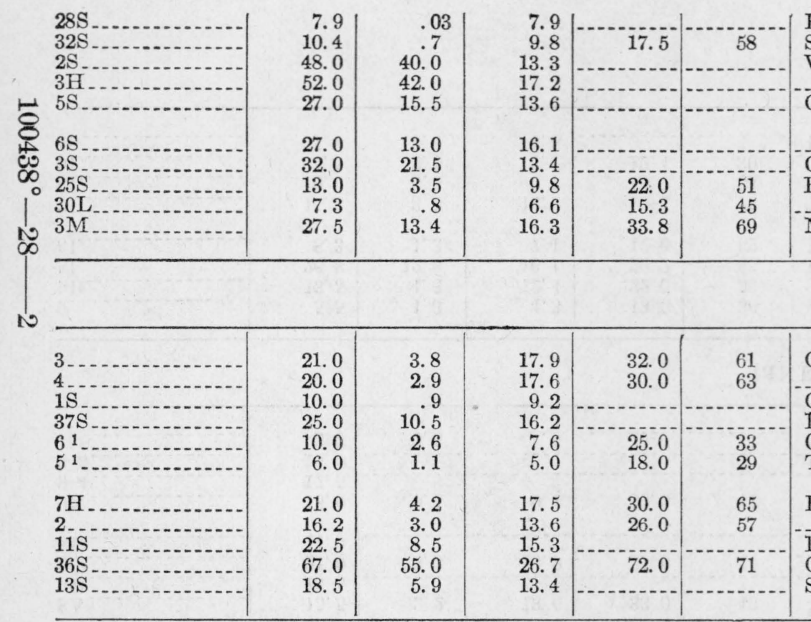

\begin{tabular}{|c|c|c|}
\hline $\begin{array}{l}\text { Flannel (outing) } \\
\text { Stocking }\end{array}$ & - do & $\begin{array}{l}\text { Light pink } \\
\text { White................. }\end{array}$ \\
\hline Voile & Plain & Wight yellow.......... \\
\hline Cotton-silk dress goods........... & Crêpe & $\begin{array}{l}\text { Light blue } \\
\text { Dark rose-... }\end{array}$ \\
\hline ....... do & Plain. & Lavender... \\
\hline $\begin{array}{l}\text { Cotton-rayon } \\
\text { Handkerchief }\end{array}$ & .......do.. & Rose \\
\hline Handkerchief.............................. & -....do do...... & White \\
\hline Mesh & Leno............. & ......................... \\
\hline
\end{tabular}

SILK

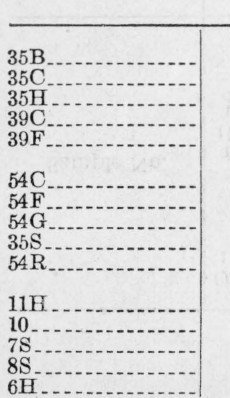

\begin{tabular}{r|r|}
18.5 & 3.7 \\
11.0 & 2.4 \\
15.0 & 2.6 \\
12.5 & 1.0 \\
8.4 & .3 \\
3.3 & .2 \\
11.5 & .7 \\
4.4 & .03 \\
7.7 & .0 \\
7.5 & .1 \\
.8 & .1 \\
2.2 & .5 \\
15.0 & 7.4 \\
7.9 & 1.0 \\
3.0 & $\ldots$ \\
\hline
\end{tabular}

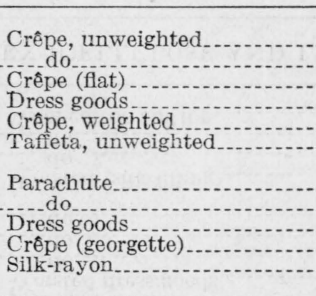
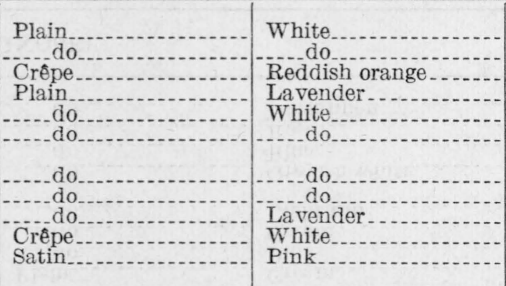

\begin{tabular}{r|r|r}
192 & 90 & 1.7 \\
135 & 80 & 2.0 \\
75 & 180 & 1.6 \\
73 & 160 & 1.1 \\
210 & 90 & 2.0 \\
122 & 90 & 2.4 \\
130 & 86 & 1.4 \\
100 & 105 & 1.8 \\
126 & 78 & 1.3 \\
92 & 80 & .6 \\
130 & 54 & 2.9
\end{tabular}

WOOL

1 Samples yellowed with age.

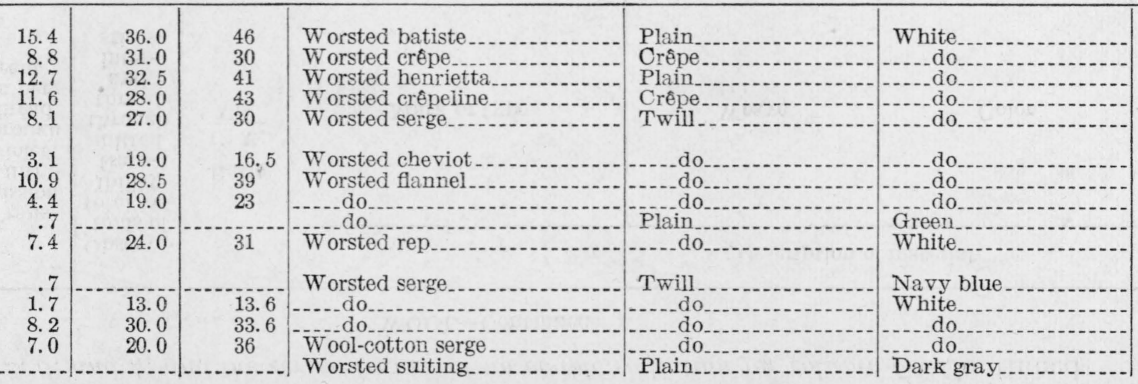

\begin{tabular}{l|l|}
63 & 62 \\
50 & 50 \\
56 & 87 \\
82 & 72 \\
91 & 72 \\
& \\
35 & 30 \\
92 & 72 \\
70 & 48 \\
32 & 36 \\
80 & 45 \\
& \\
45 & 50 \\
60 & 54 \\
70 & 60 \\
58 & 52 \\
44 & 36
\end{tabular}


TABLE 2.-Transmission in per cent of the total ultra-violet and visible radiation observed through various fabrics, using screen G986A for columns 2, 3, and 4, and the screen transmitting visible radiation for column 5-Continued

WOOL-Continued

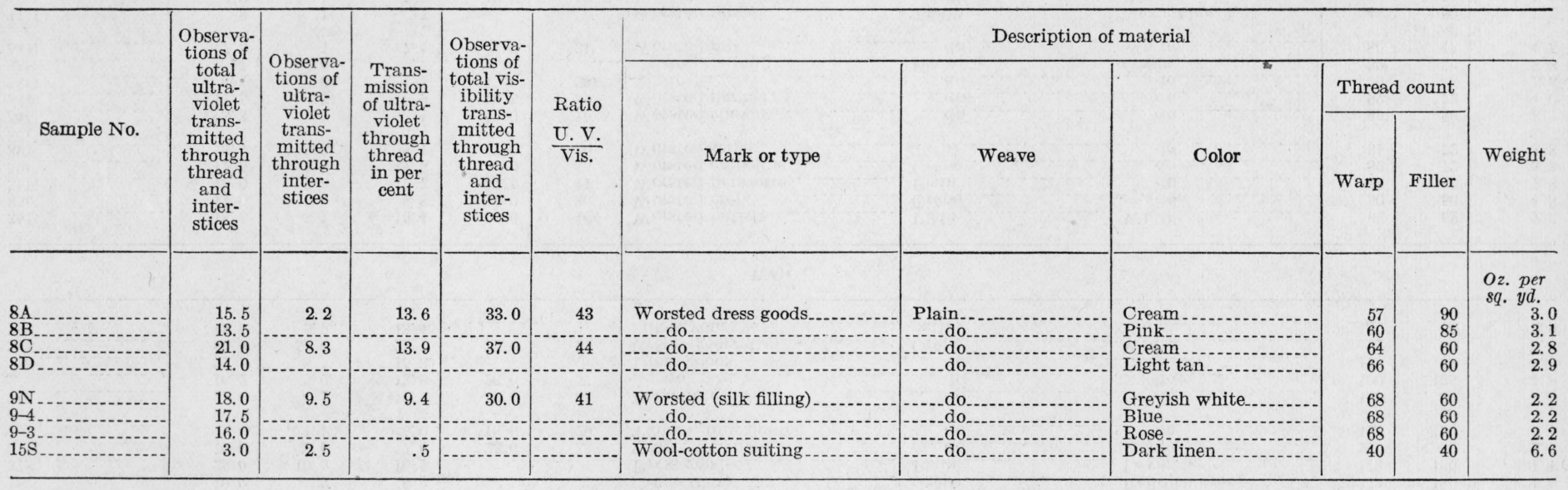

LINEN (CELLULOSE AND LIGNOSE)

\begin{tabular}{|c|c|c|c|c|c|c|c|c|c|c|c|}
\hline $9 \mathrm{~B}-\mathrm{B}^{9}$ & $\begin{array}{r}5.5 \\
13.5 \\
26.8 \\
8.3\end{array}$ & $\begin{array}{r}1.3 \\
1.3 \\
12.8 \\
1.3\end{array}$ & $\begin{array}{r}4.3 \\
12.4 \\
16.1 \\
7.1\end{array}$ & $\begin{array}{l}\text { 13. } 0 \\
22.0 \\
29.2 \\
12.6\end{array}$ & $\begin{array}{l}36 \\
59 \\
85 \\
62\end{array}$ & $\begin{array}{l}\text { Airplane } \\
\text { Handkerchief } \\
\text { Napkin }\end{array}$ & \begin{tabular}{|c|} 
Plain \\
do do
\end{tabular} & $\begin{array}{l}\text { Natural } \\
\text { White-_. } \\
\end{array}$ & $\begin{array}{r}102 \\
102 \\
90 \\
72\end{array}$ & $\begin{array}{l}99 \\
99 \\
90 \\
96\end{array}$ & $\begin{array}{l}3.8 \\
\text { 3. } 8 \\
2.2 \\
4.4\end{array}$ \\
\hline 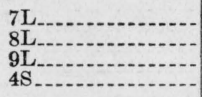 & $\begin{array}{r}15.3 \\
10.0 \\
5.5 \\
7.9\end{array}$ & $\begin{array}{l}\text { 3. } 5 \\
\text { 3. } 5 \\
2.5 \\
3.3\end{array}$ & $\begin{array}{r}12.2 \\
6.7 \\
3.1 \\
4.8\end{array}$ & $\begin{array}{l}\text { 19. } 3 \\
\text { 13. } 7 \\
12.4\end{array}$ & $\begin{array}{l}75 \\
64 \\
30\end{array}$ & $\begin{array}{l}\text { Tablecloth } \\
\text { Towel_on } \\
\text { French linen }\end{array}$ & \begin{tabular}{|c|} 
Huckaback \\
Plain
\end{tabular} & $\begin{array}{l}\text { do do } \\
\text { dight red } \\
\text { do }\end{array}$ & $\begin{array}{l}60 \\
75 \\
50\end{array}$ & $\begin{array}{l}42 \\
35 \\
45\end{array}$ & $\begin{array}{l}5.0 \\
7.8 \\
4.2\end{array}$ \\
\hline
\end{tabular}


RAYON (CELLULOSE ACETATE)

\begin{tabular}{|c|c|c|c|c|c|c|c|c|c|c|c|}
\hline 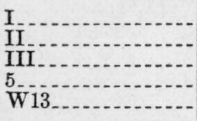 & $\begin{aligned} 14.0 \\
3.0 \\
2.2 \\
16.0 \\
8.1\end{aligned}$ & $\begin{array}{l}1.3 \\
1.3 \\
1.3 \\
.3 \\
1.5\end{array}$ & $\begin{array}{r}12.9 \\
1.7 \\
15.7 \\
6.7\end{array}$ & 23.5 & 64 & $\begin{array}{l}\text { Twill } \\
\text { Satin } \\
\text { So-no }\end{array}$ & \begin{tabular}{|c|} 
Twill \\
do do
\end{tabular} & $\begin{array}{l}\text { White } \\
\text { Yellow } \\
\text { Gold } \\
\text { White.......... } \\
\text { Orange... }\end{array}$ & $\begin{array}{l}125 \\
125 \\
125 \\
105 \\
100\end{array}$ & $\begin{array}{l}100 \\
100 \\
100 \\
115 \\
112\end{array}$ & $\begin{array}{l}2.3 \\
2.3 \\
2.3 \\
2.7 \\
2.6\end{array}$ \\
\hline $\begin{array}{l}2 \mathrm{H} \\
6 \mathrm{C} \\
\mathrm{3} \mathrm{C} \\
\mathrm{W} 20\end{array}$ & $\begin{array}{l}12.5 \\
14.0 \\
17.5 \\
25.0 \\
21.0\end{array}$ & $\begin{array}{r}.3 \\
1.5 \\
.7 \\
1.5 \\
4.3\end{array}$ & $\begin{array}{l}12.2 \\
12.7 \\
16.9 \\
23.9 \\
17.5\end{array}$ & 32.8 & 75 & $\begin{array}{l}\text { Bedspread } \\
\text { Dress goods }\end{array}$ & \begin{tabular}{|l} 
Twill \\
\hdashline.... \\
Plain \\
Twill
\end{tabular} & $\begin{array}{l}\text { Tan } \\
\text { Rose } \\
\text { Light lavender... } \\
\text { White } \\
\text { Pink }\end{array}$ & $\begin{array}{r}120 \\
90 \\
79 \\
105 \\
130\end{array}$ & $\begin{array}{l}72 \\
72 \\
80 \\
54 \\
92\end{array}$ & $\begin{array}{l}2.5 \\
3.3 \\
3.4 \\
3.0 \\
2.0\end{array}$ \\
\hline $\begin{array}{l}\text { W613 } \\
\text { WA43 } \\
\text { WA } 110 \\
\text { W36 }\end{array}$ & $\begin{array}{r}2.7 \\
12.0 \\
17.5 \\
10.5 \\
45.0\end{array}$ & $\begin{array}{r}4.2 \\
3.1 \\
41.0\end{array}$ & $\begin{array}{r}13.9 \\
7.6 \\
6.8\end{array}$ & $\cdots$ & 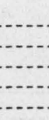 & 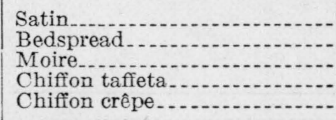 & 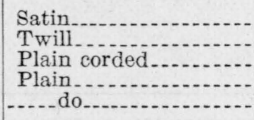 & 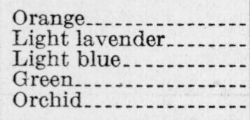 & $\begin{array}{r}170 \\
90 \\
150 \\
160 \\
92\end{array}$ & $\begin{array}{c}120 \\
72 \\
50 \\
78 \\
85\end{array}$ & $\begin{array}{l}\text { 3. } 0 \\
\text { 3. } 3 \\
3.6 \\
2.4 \\
1.5\end{array}$ \\
\hline $\begin{array}{l}101 \\
100 \mathrm{Y} \\
100 \mathrm{G}\end{array}$ & $\begin{array}{l}49.0 \\
58.0 \\
60.0 \\
55.0 \\
55.0\end{array}$ & $\begin{array}{l}35.0 \\
47.0 \\
47.0 \\
47.0 \\
49.0\end{array}$ & $\begin{array}{l}21.6 \\
20.8 \\
24.5 \\
15.1 \\
11.8\end{array}$ & & (n) & 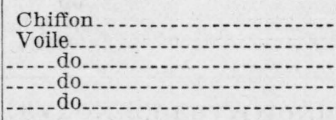 & \begin{tabular}{|l} 
do do \\
\\
\hdashline do
\end{tabular} & 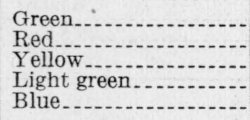 & $\begin{array}{l}82 \\
62 \\
62 \\
62 \\
66\end{array}$ & $\begin{array}{l}85 \\
62 \\
62 \\
62 \\
62\end{array}$ & $\begin{array}{l}1.7 \\
1.4 \\
1.4 \\
1.4 \\
1.4\end{array}$ \\
\hline $1 \mathrm{~A}^{2}+\ldots$ & $\begin{array}{l}60.0 \\
33.0 \\
38.0 \\
32.5\end{array}$ & $\begin{array}{l}43.0 \\
25.0 \\
23.0 \\
23.0\end{array}$ & $\begin{array}{l}29.8 \\
10.7 \\
19.5 \\
12.3\end{array}$ & $\begin{array}{l}41.0 \\
45.0\end{array}$ & $\begin{array}{l}50 \\
68\end{array}$ & $\begin{array}{c}\text { Plain knit-do } \\
\text { Po-do } \\
\text { do }\end{array}$ & Knit & $\begin{array}{l}\text { White } \\
\text { Cream } \\
\text { do }\end{array}$ & 63 & 66 & \begin{tabular}{l}
1.4 \\
$\cdots$ \\
\hdashline-
\end{tabular} \\
\hline 1C $1 \mathrm{D}$ & $\begin{array}{l}31.0 \\
30.0 \\
27.0 \\
24.5\end{array}$ & $\begin{array}{l}23.0 \\
23.0 \\
23.0 \\
23.0\end{array}$ & $\begin{array}{r}10.4 \\
9.1 \\
5.2 \\
1.9\end{array}$ & .... & & \begin{tabular}{|c|c|} 
\\
\\
\end{tabular} & \begin{tabular}{|c|} 
do do \\
do
\end{tabular} & $\begin{array}{l}\text { Dark cream } \\
\text { Light peach } \\
\text { Light yellow } \\
\text { Yellow }\end{array}$ & & & \\
\hline \multicolumn{12}{|c|}{ RAYON (VISCOSE, CELLULOSE) } \\
\hline $12 \mathrm{~A}$ & $\begin{array}{l}29.0 \\
17.5 \\
11.0 \\
26.0\end{array}$ & $\begin{array}{r}2.7 \\
.1 \\
.1 \\
12.0\end{array}$ & $\begin{array}{l}27.0 \\
17.4 \\
10.9 \\
15.9\end{array}$ & $\begin{array}{r}33.0 \\
25.0 \\
\end{array}$ & $\begin{array}{l}87 \\
70\end{array}$ & $\begin{array}{l}\text { Satin } \\
\text { Rep } \\
\text { Plain knit }\end{array}$ & $\begin{array}{l}\text { Satin } \\
\text { Rep } \\
\text { Knit }\end{array}$ & $\begin{array}{l}\text { White } \\
\text { Rose } \\
\text { Cream }\end{array}$ & $\begin{array}{l}144 \\
120 \\
120\end{array}$ & $\begin{array}{l}80 \\
54 \\
54\end{array}$ & $\begin{array}{l}2.0 \\
4.4 \\
4.4\end{array}$ \\
\hline $11 \mathrm{~A}$ & 52.0 & 39.0 & 21.3 & 56.0 & 76 & Voile-........... & Plain......... & White-................ & $67^{\circ}$ & 65 & 1.5 \\
\hline $110 \mathrm{~B}^{1}$ & $\begin{array}{l}54.0 \\
61.0 \\
59.0 \\
38.0\end{array}$ & $\begin{array}{l}45.0 \\
51.0 \\
51.0\end{array}$ & $\begin{array}{l}16.4 \\
20.4 \\
16.3\end{array}$ & & & \begin{tabular}{|c|} 
do do \\
do
\end{tabular} & do do & $\begin{array}{l}\text { Turquoise blue } \\
\text { Light yellow } \\
\text { Light blue. } \\
\text { Black }\end{array}$ & $\begin{array}{l}67 \\
62 \\
62\end{array}$ & $\begin{array}{l}65 \\
52 \\
52\end{array}$ & $\begin{array}{l}1.5 \\
1.2 \\
1.2\end{array}$ \\
\hline
\end{tabular}

${ }^{2}$ Samples $1 \mathrm{~A}$ to $1 \mathrm{~F}$ are knitted from 150 denier yarn, 30 wales and 35 courses to the inch. 
TABLE 2.-Transmission in per cent of the total ultra-violet and visible radiation observed through various fabrics, using screen G986 A for columns 2, 3, and 4, and the screen transmitting visible radiation for column 5-Continued

RAYON (NITROCELLULOSE)

\begin{tabular}{|c|c|c|c|c|c|c|c|c|c|c|c|}
\hline \multirow{3}{*}{ Sample No. } & \multirow{3}{*}{$\begin{array}{c}\text { Observa- } \\
\text { tions of } \\
\text { total } \\
\text { ultra- } \\
\text { violet } \\
\text { trans- } \\
\text { mitted } \\
\text { through } \\
\text { thread } \\
\text { and } \\
\text { inter- } \\
\text { stices }\end{array}$} & \multirow{3}{*}{$\begin{array}{c}\text { Observa- } \\
\text { tions of } \\
\text { ultra- } \\
\text { violet } \\
\text { trans- } \\
\text { mitted } \\
\text { through } \\
\text { inte:- } \\
\text { stices }\end{array}$} & \multirow{3}{*}{$\begin{array}{c}\text { Trans- } \\
\text { mission } \\
\text { of ultra- } \\
\text { violet } \\
\text { through } \\
\text { thread } \\
\text { in per } \\
\text { cent }\end{array}$} & \multirow{3}{*}{$\begin{array}{c}\text { Observa- } \\
\text { tions of } \\
\text { total vis- } \\
\text { ibility } \\
\text { trans- } \\
\text { mitted } \\
\text { through } \\
\text { thread } \\
\text { and } \\
\text { inter- } \\
\text { stices }\end{array}$} & \multirow{3}{*}{$\begin{array}{l}\text { Ratio } \\
\text { U. V. } \\
\text { Vis. }\end{array}$} & \multicolumn{6}{|c|}{ Description of material } \\
\hline & & & & & & \multirow[b]{2}{*}{ Mark or type } & \multirow[b]{2}{*}{ Weave } & \multirow[b]{2}{*}{ Color } & \multicolumn{2}{|c|}{ Thread count } & \multirow[b]{2}{*}{ Weight } \\
\hline & & & & & & & & & Warp & Filler & \\
\hline 14 & 20.1 & 0.1 & 20.0 & 25.5 & 79 & Satin & Satin & White.............. & 164 & 125 & $\begin{array}{l}\text { Oz. per } \\
\text { sq. yd. } \\
2.6\end{array}$ \\
\hline \multicolumn{12}{|c|}{ RAYON (CUPRAMMONIUM) } \\
\hline $16 \mathrm{~A}^{15}$ & $\begin{array}{l}25.0 \\
26.8 \\
13.1\end{array}$ & $\begin{array}{l}6.0 \\
9.0 \\
9.0\end{array}$ & $\begin{array}{r}20.2 \\
19.5 \\
4.5\end{array}$ & $\begin{array}{l}31.2 \\
32.3\end{array}$ & $\begin{array}{l}75 \\
76\end{array}$ & $\begin{array}{l}\text { Crêpe } \\
\text { Taffeta- }\end{array}$ & $\begin{array}{l}\text { Crêpe } \\
\text { Plain }\end{array}$ & $\begin{array}{l}\text { White } \\
\text { Brown }\end{array}$ & $\begin{array}{r}79 \\
158 \\
158\end{array}$ & $\begin{array}{l}66 \\
84 \\
84\end{array}$ & $\begin{array}{l}2.7 \\
1.9 \\
1.9\end{array}$ \\
\hline
\end{tabular}




\section{DISCUSSION OF THE TRANSMISSION DATA ON FABRICS}

Under this caption is given a summary (Tables 1 and 2) of the observations on the transmission of ultra-violet and visible radiation through various fabrics; also a comparative analysis of a few of these observations on samples typical of the group.

As already stated, by examining the same weave of cloth, white (in most cases bleached) and dyed black, it was possible to measure the transmission through the openings between the individual threads and thus determine the amount of radiation transmitted directly through the thread. Columns 2 and 5 of Table 2 give the amount transmitted through the fabric as a whole.

In this manner it was possible to study close-weave and openweave (for example, twill, satin, and voile) material and determine quantitatively the amount of ultra-violet and visible radiation transmitted through the various kinds of yarn, composed of cotton, of natural silk, of rayon (artificial silk), of linen, and of wool.

Starting with an open-weave fabric (for example, a voile weave), as is perfectly obvious, the fewer the threads per unit area the higher the transmission. But even in this case, by blackening the fabric with a dye it was possible to determine the amount of radiation obstructed or transmitted by the thread. As shown in Table 2, the transmission of radiation (for example, viscose rayon, voile No. $11 \mathrm{a}$; cellulose acetate rayon, celanese $1 \mathrm{H}$; silk georgette, $36 \mathrm{~S}$ ) through open-weave fabrics is 55 to 65 per cent, of which amount 40 to 55 per cent is transmitted through the openings between the thread. Deducting the amount transmitted through the openings between the threads, the ratio of the ultra-violet relative to the visible transmitted through the yarn ranges from 70 to 75 per cent. This is in good agreement with the measurements on similar, closely woven material (for example, the satin weaves of viscose, etc.), showing that the method is reliable.

In Table 1 are given the observed transmissions, in per cent of the total incident radiation of wave lengths at 250 to $310 \mathrm{~m} \mu$ and 310 to $400 \mathrm{~m} \mu$. The data given in columns 6 and 7 of this table are interesting in showing that these materials are more opaque in the shorter wave lengths than in the longer wave lengths of the ultraviolet. This is to be expected, of course, from our spectral transmission measurements, using homogeneous films of material and monochromatic radiation.

The data given in columns 2 and 5 of Table 1 are the same as given in columns 2 and 3 of Table 2. The data in column 2 of Table 1 are the observed measurements of the whole ultra-violet spectral region at 250 to $400 \mathrm{~m} \mu$, and, as is to be expected, they 
are about the average of the observed transmissions of the two components (250 to $310 \mathrm{~m} \mu$ and 310 to $400 \mathrm{~m} \mu$ ) of this spectral region.

Columns 6 and 7 in Table 1 and the column 4 in Table 2 give the percentage of ultra-violet incident on the thread that is transmitted through the thread. These values are obtained by deducting from the observed transmissions in column 2 the amount of radiation transmitted through the openings between the threads (column 3 of Table 2) as determined by measurements on the blackened material. For example, since the sample of white muslin, $24 \mathrm{~S}$, transmitted 2.2 per cent through the holes between the threads, 97.8 per cent of the total area was occupied by the threads. Hence, referring to Table $1(10.4-2.2) \div 97.8=8.4$ per cent is the amount of ultra-violet of wave lengths 250 to $310 \mathrm{~m} \mu$ transmitted through the threads of this sample of muslin.

In the same manner the visible radiation transmitted through the thread might be obtained from column 5 . However, it seemed instructive to record also the ratio of the transmissions of the ultraviolet to the visible (columns 2 and 5 ) after deducting the amount transmitted through the interstices. These ratios are given in column 6. They serve as a measure of the absorption in the ultra-violet. For example, they show very effectively that the ultra-violet transmission ranges from 14 per cent (wool No. 10) to 87 per cent (viscose satin No. 13) of that of the visible spectrum. Furthermore, these ratios show that the ultra-violet transmission relative to the visible is much higher (70 to 87 per cent) for the pure white cellulose (cotton and viscose rayon) than the cellulose acetate rayon, which gives ratios of 50 to 75 per cent. Of course, the absolute values of the ultra-violet transmissions of the threads given in column 4 of Table 2 also show this condition, but this method of recording the data accentuates errors of observation which are eliminated to some extent by taking ratios, which serves as a check on the accuracy of the measurements.

As is to be expected, since there are probably no narrow absorption bands, the transmissions of these wide bands of spectral radiation represent averages which approximate the values that would be obtained from monochromatic transmission curves. For example, the sample of cotton, $30 \mathrm{~L}$, has the following gradually increasing transmissions of $3.8,9.2$, and 15.3 per cent, respectively, for the spectral regions of 240 to $310 \mathrm{~m} \mu, 310$ to $400 \mathrm{~m} \mu$, and 400 to $750 \mathrm{~m} \mu$.

Considered as a whole, these data show the much greater absorption of the short wave length ultra-violet rays than those in the visible spectrum; and they disclose quite conspicuously the very rapid increase in absorption of these short wave-length rays by a slight discoloration or tinting of the fabric-as, for example, the unbleached 
cotton or the yellowing of the (natural) silk fabric-in comparison with the bleached cotton or white silk. Further examples are the dyed samples of cellulose acetate twill (I, II, III) and those of the open-weave rayon fabric (1a to $1 \mathrm{~b}$ ), which was dyed different shades of yellow.

\section{COTTON FABRICS}

Taking the opposite extreme, of closely woven fabrics, only 1 to 4 per cent of the total incident radiation is transmitted through the interstices, while a surprisingly large amount of ultra-violet and visible radiation is transmitted through the thread.

For example, a thin-bleached cotton fabric ( $7 \mathrm{~b}$ in Table 2) transmitted 24 per cent of the total incident ultra-violet radiation, of which amount only 3.9 per cent of the incident radiation was transmitted through the openings between the yarn. The ratio of ultraviolet to visible is 77 per cent, showing that the bleached material absorbed but little ultra-violet, relative to the visible rays. In marked contrast, the unbleached cotton material (No. 7) transmitted only 8.4 per cent of the ultra-violet, of which amount 3.9 per cent passed through the interstices.

As a wearing material the white cotton nainsook, $4 \mathrm{H}$, and the cotton batiste, $5 \mathrm{H}$, have a high transmission of ultra-violet radiation, amounting to about 20 per cent, most of which passed through the thread, showing the great transparency of the bleached cotton thread to ultra-violet radiation.

\section{LINEN FABRICS}

The samples of linen which were bleached were found to be highly transparent to ultra-violet radiation, but the transmission of the unbleached material was low. In general, it appears that the average bleached sample of linen transmits about as much of the ultra-violet as bleached cotton.

\section{SILK FABRICS}

The natural silks, when not yellowed with age, have a high transmission of ultra-violet radiation. For example, a white silk crêpe (No. 4 in Table 2) transmitted 20 per cent of the ultra-violet, of which amount less than 3 per cent passed through the interstices. Similarly, the plain woven silk, $7 \mathrm{H}$, had a high transmission. However, the transmission of ultra-violet radiation relative to visible radiation through natural silk is distinctly lower than through cotton, the ratio being of the order 60 to 65 per cent in comparison with 65 to 84 per cent through cotton. Moreover, the ultra-violet rays (and to a less extent the longer wave lengths) are greatly absorbed by natural silk that is yellowed with age. 


\section{WOOL FABRICS}

Some of the most transparent white wool fabrics (serge, 8S) examined by us transmitted only about one-half as much ultraviolet as the most transparent cotton yarns. Some samples (for example, a cream-colored worsted, $8 \mathrm{~A}$ ) compared favorably with the best silks in transparency, while one sample (a worsted, 8C) transmitted 21 per cent, of which 8.3 per cent passed through the

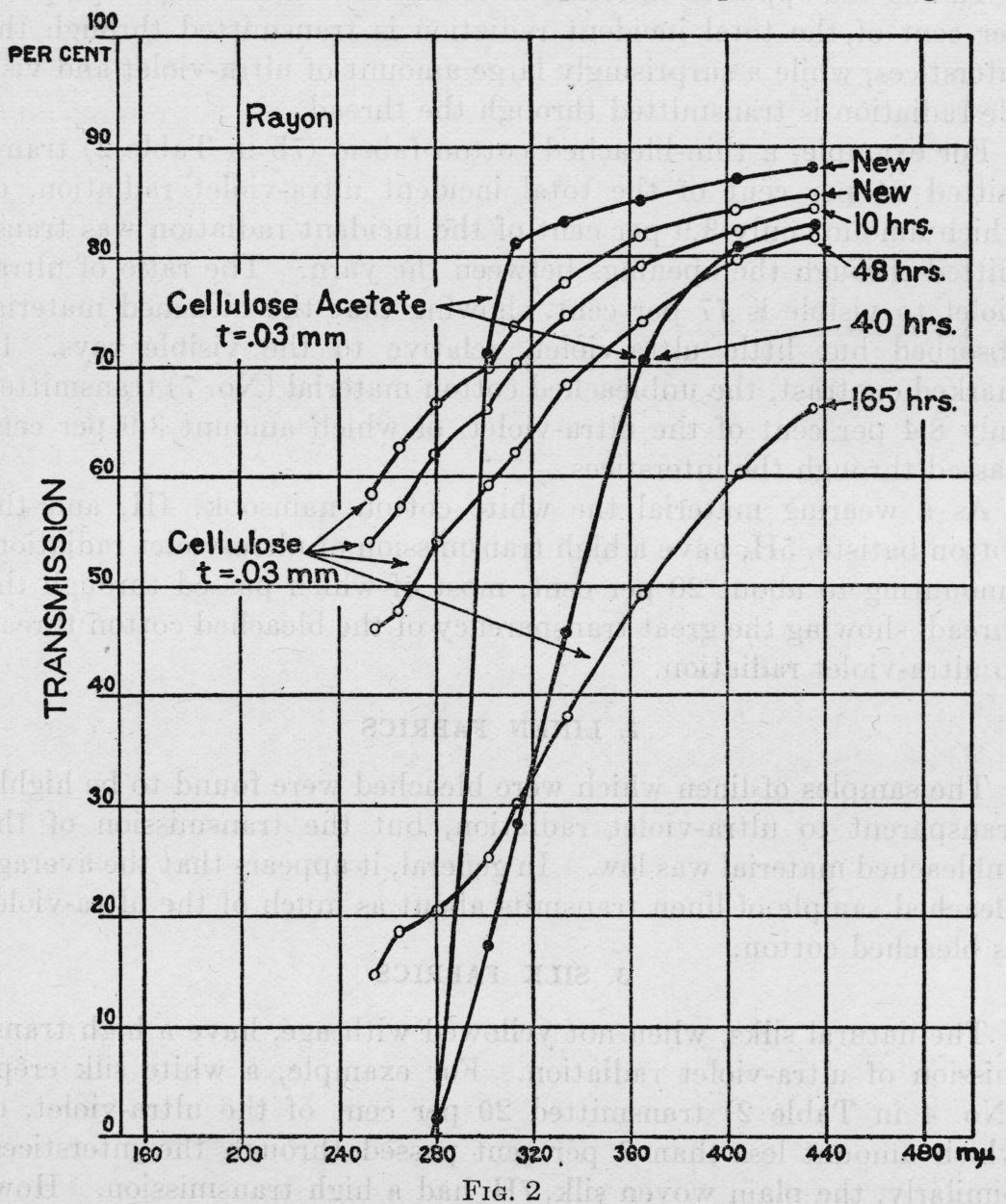

interstices. The transmission of ultra-violet relative to visible radiation of a number of samples was 44 per cent, which is a good showing in comparison with 65 to 84 per cent through cotton.

\section{RAYON FABRICS}

Rayon (formerly known as "artificial silk") is the generic name of filaments made from various solutions of modified cellulose, which is obtained commercially from cotton linters and from wood pulp. We 
have examined rayons made by the following processes: (1) Nitrocellulose or chardonnet, (2) cuprammonium, (3) viscose, and (4) cellulose acetate - the latter under the trade name celanese.

In Figure 2 is shown the spectral transmission of thin homogeneous films of different kinds of rayon before and after exposure to ultraviolet light. When new, the pure cellulose and the cellulose acetate differ but little in transmission of radiation of wave lengths greater than $300 \mathrm{~m} \mu$, which includes the most of the short wave length solar radiation that has an activating, vitalizing, therapeutic action.

Our tests show that, on an average, viscose and cuprammonium rayon transmit practically as much ultra-violet radiation as the most transparent samples of white cotton, having a ratio of transmission of ultra-violet to visible radiation amounting to 70 per cent (viscose rep, 12a, Table 2) in comparison with 65 to 84 per cent through cotton. One sample of white satin viscose rayon (13) even excelled cotton, having a relative transmission of ultra-violet to visible amounting to 87 per cent. This seemed so unusually high that the observations were repeated with especial care. The new ratio of ultra-violet to visible was found to be 88 per cent, verifying the earlier measurements. This is probably to be expected in view of the fact that the viscose rayon thread is composed of a number of long, practically untwisted filaments, while the cotton thread is composed of numerous short filaments which scatter the radiation.

The average cellulose acetate rayon fabric appears to be as transparent as the pure cellulose, whether in the form of cotton or viscose. But some samples (for example, the cellulose acetate rayon satin, 5, and twill, I) transmit only 13 to 16 per cent of the incident ultraviolet light. This is observed also in the open-weave fabrics of cellulose acetate rayon, $1 \mathrm{a}$ and 2 . One very thin sample of the acetate rayon (No. 4) transmitted $29.8^{*}$ per cent of the incident ultraviolet radiation.

In all cases the transmission of the ultra-violet relative to the visible through white cellulose acetate rayon is distinctly lower than that observed through cotton and through viscose rayon, ranging from 50 to 75 per cent as compared with 65 to 87 per cent through the pure cellulose fabrics. This is to be expected from the measurements on the homogeneous film of the acetate rayon, which shows strong absorption in the ultra-violet.

From Tables 1 and 2 it appears that, after deducting the light transmitted through the openings between the threads, the percentage of transmission of ultra-violet radiation through the bleached, white threads are as follows:

Viscose rayon varies from 16 to 27 per cent.

Cotton varies from 14 to 21 per cent.

Cellulose acetate rayon varies from 11 to 29 per cent. 
Silk varies from 14 to 18 per cent.

Linen varies from 7 to 16 per cent.

Wool varies from 5 to 15 per cent.

The great variation in transmission (11 to 29 per cent) of ultraviolet through the cellulose acetate rayon is no doubt owing to the high absorption of this material at $300 \mathrm{~m} \mu$ (see fig. 2), which produces a great variation in transparency for a small variation in thickness.

\section{CONCLUDING REMARKS}

As distinctly emphasized in the beginning of this paper, in order to obtain a reliable comparison between the various kinds of materials of which the fabrics are made it is necessary to examine black and white samples of the same cloth; also to examine different kinds of weaves; and finally to determine the effect of dyes. The latter would be an interminable undertaking, hence we have not examined very deeply into it. However, we have tabulated sufficient data to demonstrate the rapid decrease in transmission of ultra-violet radiation by red, orange, yellow, green, and tan colored dyes (pink seems to be an exception), which render these yarns almost, if not completely, ofaque to ultra-violet radiation. Even a slight yellowing with age decreases the ultra-violet transmission.

Our measurements show that, after deducting for the openings between the threads, the transmission through the thread, especially when dyed, is only of the order of about 5 to 10 per cent. When one considers that the thread usually occupies from 95 to 99 per cent of the total space, a transmission of only 10 per cent of the total incident light is insignificant, and, since it is usually not practicable to have all fabrics uncolored, it is evident that the real gain in transparency to ultra-violet radiation is obtained by using an open-weave fabric. On this basis fabrics made of silk and the heavy wool yarns compare favorably with cotton and rayon for transmitting the ultra-violet. Evidently the question of the composition of the material for transmitting the ultra-violet is overestimated. This is illustrated in Table 2, in which white samples of cellulose acetate rayon (Twill I, II, III, and the open mesh, 1a to $1 \mathrm{~b}$ ) were dyed different shades of yellow, resulting in a rapid decrease in transmission from 20 per cent to less than 2 per cent through the latter fabric.

The foregoing discussion relates to the transmission of a single layer of fabric. In passing through two (or more) layers, as would be the case when more than one garment is worn, the transmission of ultra-violet radiation (also the visible radiation) is greatly decreased. This is shown by actual measurements on a sample of cotton broad cloth (similar to sample $3 \mathrm{~B}$ of Table 2), as follows:

1 thickness transmitted 21.5 per cent.

2 thicknesses transmitted 8.0 per cent.

3 thicknesses transmitted 2.9 per cent.

4 thicknesses transmitted 1.7 per cent. 
Whether there is justification for current opinion as to the importance of exposing the body to ultra-violet (solar) radiation remains to be determined. For young children, under proper medical supervision, it is known to be beneficial. But from the fact that adults have lived, fully clothed and in health all these years prior to the present discussion of the subject, it would appear that it requires but a small amount of these ultra-violet rays to keep the body in health; and that, until we know more about the biological effects of excessive amounts of ultra-violet rays, it would be wise to be cautious in exposing our food as well as our bodies to ultra-violet radiation. A note of warning has already been sounded by Price ${ }^{7}$ regarding the injury that may result from missuse of the ultra-violet rays in activating foods.

In conclusion, it is relevant to refer to these data in connection with the question of shielding the body from ultra-violet and visible solar radiation, which is an important problem in the Tropics. As shown in a previous paper, ${ }^{8}$ the best reflector for sunlight is a closely woven white fabric. To prevent heat radiation.from falling upon the head, the underside of headgear may be painted with aluminum paint, suitable provision having been made for ventilation, as in the well-known helmets worn in the Tropics. For protecting the body from the ultra-violet rays transmitted through the outer clothing (which should be white in order to have a high reflecting power), the inner garment may be made of thin, closely woven yarn, of wool or cotton, dyed (red or khaki) with a substance that absorbs the ultra-violet. Obviously there are other applications, but it seems beyond the scope of this paper to attempt a further interpretation of the data at this time.

\section{TRANSPARENCY OF FEATHERS AND ANIMAL TISSUE}

In connection with the foregoing measurements on fabrics, it was of interest to determine the transmission of radiation through feathers. The information obtained is of interest in connection with the problem of irradiating fowls with ultra-violet light.

For convenience and accuracy, the measurements were made on continuous areas (free from interstices) of large-sized primary and secondary wing coverts. The body feathers would be thinner and individually (that is, not overlapping) would be more transparent.

The data obtained are given in Table 2. They are interesting in showing a fairly high transmission, even for the colored feathers. The feather from the white swan was an unusually fine specimen

T Price, J. Amer. Dental Assn., 13, p. 1765; 1926.

Coblentz, B. S. Bull. No. 196, 9, p. 283; 1913. Coblentz and Hughes, B. S. Tech. Paper No. 254, 18, p. $171 ; 1924$. 
that was quite translucent and homogeneous, without interstices, as viewed through a reading glass.

The sample of animal tissue examined consisted of the thin outer wall of the intestine of a freshly killed chicken. The material, 0.05 $\mathrm{mm}$ in thickness, was placed between two plates of quartz and the edges sealed to retain the moisture. The data are of interest in connection with the question of the penetration of ultra-violet radiation into the body, for therapeutic purposes. ${ }^{9}$

Washington, February 14, 1928.

As this paper goes through the press a similar research by Hirst, King, and Lamaert, Soc. of Dyers and Colorists, 44, p. 109; April, 1928; practically confirms our work on the transmission of ultra-violet radiation through various fabrics, previously reported in B. S. Tech. News Bulletin, No. 126, of October, 1927. 